\title{
TEXT LINGUISTICS AND CRITICAL DISCOURSE ANALYSIS: A MULTIMODAL ANALYSIS OF A MAGAZINE ADVERTISEMENT
}

Sidnéa Nunes Ferreira

Universidade Federal de Santa Catarina

Viviane M. Heberle ${ }^{1}$

Universidade Federal de Santa Catarina

\begin{abstract}
Drawing on Fairclough's (1995) three-dimensional framework of discourse analysis of communicative events, in this paper we carry out a multimodal analysis of a Diners Club International magazine advertisement. Moving from the description of how textimage (Mitchell 1995) constructs a problem-solution structure in the advertisement to the discussion of its discourse and sociocultural practices, the paper foregrounds a multilayered ideological message, besides the construal of a need (problem) for a product (solution). Through its multimodal structure, the advertisement seems to tap on two important sociological issues: the avoidance of human togetherness and the colonization of travelling by consumer markets (Bauman 2007). Keywords: problem-solution, text-image relations, logic of appearances and explanatory logic.
\end{abstract}

\begin{tabular}{|l|l|l|l|l|}
\hline Ilha do Desterro & Florianópolis & $n^{\circ} 64$ & p. 111-133 & jan/jun 2013 \\
\hline
\end{tabular}


112 Sidnéa Nunes Ferreira and Viviane M. Heberle, Text Linguistics...

\section{Introduction}

The organization of most advertisements in a problem-solution pattern (Hoey \& Winter 1986; Hoey 2001), one of the most common rhetorical patterns in our society, has already been pointed by, among others, Jordan (1984), McCarthy and Hewings (1988), Meurer (1997), Hoey (2001), and Fairclough (2003). In the examples that these authors offer, the problem is usually "the need or desires attributed to potential consumers" while the solution is the very product being announced, as Fairclough (2003, p. 91) summarizes it. In all these cases, however, the focus of analysis has been on the conventional structure of the advertisements only, leaving aside any visual semiotic resource that may have been deployed. A recent study on global genres by Machin and van Leeuwen (2007), however, addresses the problem-solution pattern incorporating visual semiotics in their analysis of a Health Diet Clinic.

Considering these previous linguistic studies on the problemsolution pattern and expanding on the discussion proposed by Machin and van Leeuwen (2007), this paper aims at conducting a multimodal problem-solution analysis of a Diners Club International magazine advertisement (Figure 1). The paper also argues for the multimodal nature of advertising discourse and the increasing concern with understanding the relationship between text and image in communication (Kress \& van Leeuwen, 2006; Unsworth 2001; Cope \& Kalantzis 2000; Kalantzis \& Cope, 2012). More specifically, its first objective is to describe how textimage (Mitchell 1995) ${ }^{1}$ constructs the problem-solution structure of the advertisement. 


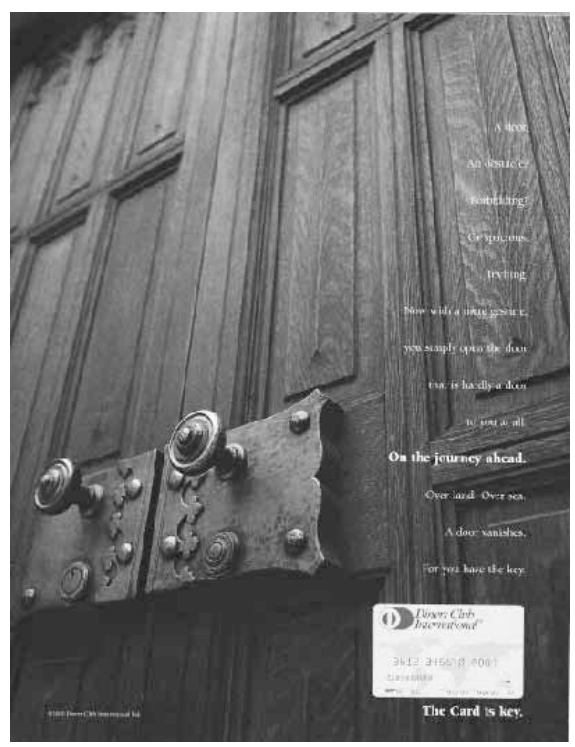

Figure 1 - Diners Club International advertisement. From Newsweek - Latin America Edition, No photo credits given.

A second objective of this paper, following Fairclough's (1995; 2010), three-dimensional framework of discourse analysis is to move from the level of description to the levels of interpretation and explanation. That is, after describing textimage from the perspective of higher level semantic relations (Winter 1982; Hoey \& Winter 1986; Hoey 2001), the present work focuses on the discussion of both the discourse practice and the sociolcultural practice in which the advertisement is embedded. In relation to the discourse practice, the focus is on the processes of production and consumption as well as on possible traces of intertextuality present in the advertisement. And, in relation to the sociocultural practice, the focus is on Fairclough's concept of logic of appearances versus explanatory logic (Section 2), with Bauman's (2007) sociological observations on modernity as a 
114 Sidnéa Nunes Ferreira and Viviane M. Heberle, Text Linguistics...

theoretical support. Table 1 shows a summary of Fairclough's three dimensional framework along with our questions which guide this paper. We emphasize that description, interpretation and explanation are not clear-cut categories and that the order selected here, from micro-analysis to macro-analysis, is a way of rhetorically organising the analysis. There are occasions, however, where the discussion of the three levels may merge into each other.

Table 1 - Fairclough's three dimensional framework (1995, p. 59; 2010) and the guiding questions for this paper.

SOCIOCULTURAL PRACTICE: explanation of both the discourse practice and the textimage analysis in the light of the sociocultural practice in which the advertisement is embedded.

What's the ideological message (logic of appearances vs explanatory logic) that the advertisement may convey?

DISCOURSE PRACTICE: interpretation of the discourse practice

How is the advertisement produced and consumed?

Any traces of intertextuality?

TEXT: description of the textimage

How does textimage construct the problem-

solution structure of the advertisement?

\section{Theoretical background: Text Linguistics, Multimodality and Critical Discourse Analysis}

To a certain extent, this paper shares Fairclough's (2003, p.53, 54, 58) concern with: 1) the need to conduct the analysis of "photographic images, layout and the overall visual organisation 
of pages" and how these visual elements "interact with language in producing meanings"; and 2) the need "to combine the insights of recent social theory with traditions of close textual analysis" in order to "develop a form of discourse analysis which can contribute to social and cultural analysis as a whole".

In relation to the first need, the approach adopted in this paper is theoretically grounded mainly on a combination of studies on the problem-solution pattern developed in Text Linguistics (Hoey \& Winter 1986; Jordan 1984; Meurer 1997; McCarthy \& Hewings 1988; Hoey 2001; and Fairclough 2003) and on the Grammar of Visual Design developed by Kress and van Leeuwen $(1996,2006)$ in the field of Multimodality. Text Linguistics has identified a sequence of four principal steps in the problem-solution pattern: 1) the introduction of a situation, 2) the description of a problem, which is usually a consequence of the situation previously introduced; 3 ) the proposal of a solution to the problem; and 4) the evaluation of the solution proposed. These steps, as McCarthy and Hewings (1988, p. 4) point out, "do not necessarily coincide with sentences. They may consist of less than a sentence, one sentence, or several sentences". In the case of the multimodal data of this paper, these steps may also consist of conjunctions of text and image, and it is in this aspect that the present work, in a certain way, innovates. Departing first from Mitchell's (1995, p. 89) point of view that "comparison itself is not a necessary procedure in the study of text-image relations", the paper tries to work with the textimage in the Diners Club International advertisement. The challenge, therefore, is not to describe the meanings that one mode realises in opposition to the other mode, but to focus on how textimage (together) constructs the problem-solution pattern. Kress and van Leeuwen's $(1996,2006)$ Representational, Interactive and Compositional visual systems 
which realise ideational, interpersonal and textual functional meanings, respectively, also play a significant role in the analysis of the meanings conveyed in the advertisement. In the interest of concision, however, these systems and the kind of meanings they may construct are signalled within data analysis (Section 3.2).

Regarding the second need, this paper follows Fairclough's (2003) statement that focusing on higher semantic relations, such as the problem-solution pattern, may help to elucidate a number of social research issues like legitimation, equivalence and difference, and logic of appearances versus explanatory logic. Our emphasis here is upon the last, which has to do with a current preference for simply reporting events at face value (logic of appearances) as opposed to considering them as causal effects of structures (explanatory logic - Fairclough, 2003). More specifically, by making connections among the description of the multimodal problem-solution pattern of the advertisement, the interpretation of its conditions of production and consumption, and the presence of possible traces of intertextuality in it, we investigate how the action of engaging with a closed door is presented as a problem (which instantiates a scenario for a solution) to those who travel abroad with no references to possible reasons for such problem. We also attempt at relating this resulting "surface" appearance to Bauman's (2007) observations on modernity. Among the topics explored by Bauman, we focus on the issue of avoidance of human togetherness and the increasing colonization of social spaces by consumer markets. These topics are also more fully explained within the analysis that follows (Section 3.4). 


\section{Data analysis}

\subsection{Introducing the data}

The selected Diners Club International advertisement is a one-page magazine advertisement published in Newsweek - Latin America Edition on December 23rd, 2002. The advertisement (Figure 1) can be visually divided in at least three components: 1 ) a photo of a closed massive wooden door with two heavy metal doorknobs and lock, which covers the whole page, 2) a verbal text in white (probably) Times New Roman font, vertically displayed on the right side of the advertisement, and which contains another photo: a small $^{2}$ fictional Diners Club International credit card, and 3) Diners Club International copyright logo at the bottom of the page, on the left side of the advertisement. The verbal text described in item 2 reads as follows ${ }^{3}$ :

1) A door.

2) An obstacle?

3) Forbidding?

4) Or spacious.

5) Inviting.

6) Now with a mere gesture,

7) you simply open the door 
118 Sidnéa Nunes Ferreira and Viviane M. Heberle, Text Linguistics...

8) that is hardly a door

9) to you at all.

10) On the journey ahead.

11) Over land. Over sea.

12) A door vanishes.

13) For you have the key.

[Photo of the credit card]

14) The Card is key.

\subsection{Problem-solution in Diners Club International adver- tisement: describing textimage}

Congruently with the four-part problem-solution pattern previously described (situation-problem-solution-evaluation), the Diners Club International advertisement starts with two steps being visually realised at once: situation and problem. In the advertisement, viewers are faced with a very close shot of a massive wooden door. More specifically, viewers are faced with a slightly oblique low angle representation of (mainly) two metal doorknobs and lock as well as part of the top half of a door, which puts them, unequivocally, in a position of powerless engagement with the object (Kress \& van Leuween's Interactive system - Attitude; 1996, 2006). Here the problematic situation begins and it is echoed by the first three lines of 
the verbal text: 1) "A door." which confirms viewers' identification of the situation: "a closed door"; 2) "An obstacle?" and 3) "Forbidding?" which corroborate the visual interpersonal meaning of powerlessness and, therefore, constitute an initial version of the problem: to be faced with a closed massive wooden door from a disadvantaged position. This problem, however, is further elaborated in the next two lines. In contrast with the two previous interrogative sentences 2) "An obstacle?" and 3) "Forbidding?", the affirmative sentences 4) "Or spacious." and 5) "Inviting." - followed by full stops, not question marks - signal positive alternative positions in relation to the door. That is, the verbal text suggests that a closed door can be either an obstacle/forbidding or spacious/inviting. Putting together all meanings discussed so far, the problem seems to be a matter of how to guarantee that one's engagement with a closed massive wooden door will turn out to be positive (spacious and inviting) and not negative (obstacle and forbidding) as represented in the textimage.

Notice that the reading path (Kress \& van Leeuwen; 1996, 2006) just described (photo of the door $\rightarrow$ verbal text in white) offers two possible detours. First, at the same time that the upper corner of the metal plaque behind the first doorknob, the most salient element in the composition, directs viewers' eyes to begin reading the text, the bottom part of the same metal plaque (and the oblique angle of the photo) encourages viewers' eyes downwards to the picture of the credit card, line 14) "The Card is key" and, perhaps, line 10) "On the journey ahead" in large bold letters. From this perspective, it is possible to argue that viewers may glance at these pieces of information before engaging with the text. In this sense, viewers may already be aware of the final solution (the credit card itself) and the second situation (discussed later on) when moving to the verbal text as described before. A second possible detour is that viewers may refuse reading 
the verbal text. In this case, the composition of the advertisement is quite clever because it permits a fast track for those not in the mood to read; only the visual version of the problem (the daunting engagement with a closed door), the solution (the photo of the credit card reinforced by line 14) "The Card is key") and the second situation (line 10) "On the journey ahead" - discussed later on). The last two pieces of information may even be glanced at simultaneously. Figure 2 presents the possible reading paths just discussed.

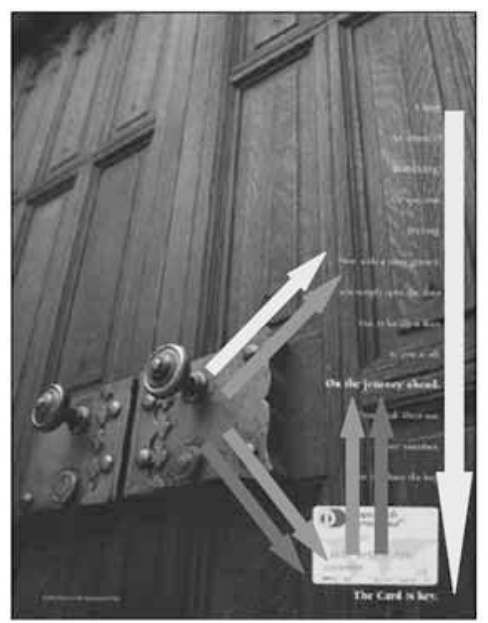

Figure 2 - Possible reading paths in Diners Club International advertisement.

1) Yellow arrows: from the most salient doorknob to the verbal text and, then, through the verbal text, to the photo of the credit card and the last line of the verbal text.

2) Red arrows: from the most salient doorknob, viewers glance at the credit card, the last line of the verbal text and, perhaps, the second situation line before engaging with the whole verbal text.

3) Blue arrows: a fast track; viewers do not read the verbal text, only move from the most salient doorknob to the credit card, the last line of the verbal text and, finally, to the second situation line. It is also possible that the last three pieces of information are glanced at simultaneously. 
The sentences 7) You simply open the door", 8) "that is hardly a door", and 9) "to you at all.", in constant dialogue with the massive look of the closed door in the image, tell viewers that that door, presumably after the implied solution is applied, simply opens with little effort. These lines do not seem to follow the conventional problem-solution pattern previously presented (Section 2). In fact, they may be interpreted as introducing an extra step: an evaluation of the easy procedure to go for the final solution. In other words, these lines tell viewers that the final solution to be offered does not require any complicated procedure. In fact, the strong contrast of the lexical choices "mere gesture", "simply open" and "hardly a door" together with the image of the heavy door seems to add some magical power to the effortless opening of the door. The evaluation of the procedure required to go for the final solution, therefore, is more than positive: "It's like magic: with little effort the door simply opens".

Still in reference to the verbal text, the next step introduced is a particularization of the visual/verbal situation/problem previously introduced: "a closed door". In bold letters, line 10) "On the journey ahead." contextualizes the scenario of the door viewers are engaged with. The door does not seem to belong to viewers' every day environment, but it is placed in the context of journeys: "Over land." and/or "Over sea." (Line 11). One conceivable explanation for the choice of bold letters for line 10 is related to the detours described before. That is, for those viewers who hesitate to engage with the verbal text, this bold line may function not only as a reminder of the situation in which the solution (the photo of the credit card reinforced by line 14) "The Card is key") would be useful, but also as a visual track back to the departing point of the advertisement and, perhaps, now to the verbal text. Observe that the white of the bold letters of line 10 matches the prevailing whiteness of the credit card 
and the last line of the verbal text (Line 14), forming a triangle with the departing point of the reading path, the first doorknob with a white reflection (Figure 3). The choice for bold letters may also be interpreted as a direct way of addressing the target audience and it is further discussed in the next section (Section 3).

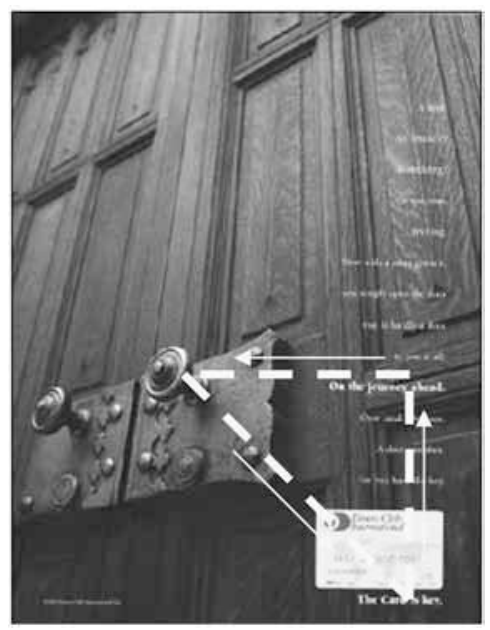

Figure 3 - The second situation line in bold functioning as a visual track back to the departing point of the advertisement, the first doorknob.

Finally, the last step is presented. The key to the door or the solution to the problem is verbally and visually displayed in the advertisement. First, in the verbal text, with lines 12) "A door vanishes." and 13) "For you have the key." which come in a consequence/cause enhancing relation (Halliday \& Matthiessen, 2004). That is, a key that viewers supposedly possess (solution) is the cause for the door to vanish. Next, the solution is presented visually, with a photo of a small fictional Diners Club International credit card, specifying the kind of key meant. Notice that on this card, in the place reserved 
for a person's name, there is only the word "cardmember" in capital letters, and information on the validity of the card is missing. It is clear, therefore, that this credit card is ready to suit any viewer. Last but not least, the solution is verbally repeated in line 14) "The Card is key." in the same bold white letters observed in line 10) "On the journey ahead." and, therefore, visually linked to it (Figure 3). In this last line, the word "key" appears a second time but now with a broader meaning. In a sense, it still refers to the object that unlocks doors but it also seems to mean "the answer to a problem" and/or "an indispensable item to those travelling". The definite article and the capital " $C$ " in the word "Card" corroborate the semiotic construal that only Diners Club International (a credit card which closely resembles the one above the line) can be the key.

Still in reference to the solution, an interesting observation is that the shape of the verbal text and the credit card somehow form the outlining of an imaginary key ${ }^{4}$. If this outlining is taken in consideration, then, the solution step is again visually realized. Finally, while the photo of the door, which visually introduces the situation and the potential problem, is presented in an oblique angle, the text and the photo of the card are displayed in a parallel plane to that of the viewers. This difference in angles creates detachment in relation to the door (the situation and potential problem) but engagement in relation to the text and the credit card (the solution) (Kress \& van Leuween's Interactive system - Attitude; 1996, 2006). Table 2 attempts at summarizing the description of the problemsolution pattern in the Diners Club International advertisement. 
124 Sidnéa Nunes Ferreira and Viviane M. Heberle, Text Linguistics...

Table 2 - Summary of the problem-solution structure in the Diners Club International advertisement.

\begin{tabular}{|l|l|}
\hline $\begin{array}{l}\text { Problem-solution structure } \\
\text { in 'Diners Club International } \boldsymbol{a} \boldsymbol{d}^{\prime}\end{array}$ & $\begin{array}{l}\text { Meanings realised } \\
\text { by textimage }\end{array}$ \\
\hline 1. Situation (1) & A closed door. \\
\hline 2.Problem & $\begin{array}{l}\text { How to guarantee that one's en- } \\
\text { gagement with a closed massive } \\
\text { wooden door will turn out to } \\
\text { be positive (spacious/inviting) } \\
\text { and not negative (obstacle/for- } \\
\text { bidding) as represented in the } \\
\text { textimage. }\end{array}$ \\
\hline $\begin{array}{l}\text { 3. Evaluation of procedure to go for } \\
\text { final solution }\end{array}$ & $\begin{array}{l}\text { Positive - It's just like magic: } \\
\text { with little effort the door simply } \\
\text { opens. }\end{array}$ \\
\hline 4. Situation (2) & $\begin{array}{l}\text { On journeys over land and/or } \\
\text { over sea. }\end{array}$ \\
\hline 5. Solution & $\begin{array}{l}\text { The Diners Club International } \\
\text { credit card is the key. }\end{array}$ \\
\hline
\end{tabular}

\subsection{Addressing "The best of today's New Economy consum- ers" with art: interpreting the discourse practice}

As mentioned before, the Diners Club International advertisement appears in an issue of Newsweek, the International Newsmagazine, more specifically, in the Latin America edition. Therefore, given the high professional level of the media in which the advertisement circulates, it is reasonable to draw two conclusions: 1 ) that in terms of processes of production, Diners Club International Ltd has probably hired a publicity agency to create their advertisement, and 2) that 
in terms of processes of consumption, the target audience of the advertisement probably conflates with that of the magazine.

Regarding the first conclusion, it is also very likely that the processes of production of the advertisement have involved many different stages, from choosing the most suitable publicity agency to actually launching the advertisement, and a great number of different professionals, such as graphic designers, technicians, writers, photographers, editors and so on. This type of complex context of production has already been identified by Caldas-Coulthard (1997) in her study of news in the British written press, and it is said to contribute to a lack of sense of authorship and responsibility for the final text (in the present case, the final textimage). It is also probable that most of the target audience for the advertisement is not aware of all changes that the advertisement may undergo during its elaboration and the numerous contributors involved in it. Kress and van Leeuwen, (1996, p.119), writing about photos in magazines, describe the common discrepancy between the multifaceted processes of production on the one hand, and the magazine audience on the other:

Think of photographs in magazines. Who is the producer? The photographer who took the shot? The assistant who processed and printed it? The agency who selected and distributed it? The picture editor who chose it? The layout artist who cropped it and determined its size and position on the page? Most viewers will not only never meet all these contributors to the production process face to face, but also have only a hazy, and perhaps distorted and glamourized idea of the production processes behind the image. All they have is the picture itself, as it appears in the magazine. And producers, similarly, can never really know their vast and absent audiences, and must, instead, create a mental image of 'the' viewers and 'the' way viewers make sense of their pictures.' 
In terms of the context of consumption, the target audience of the Diners Club International advertisement can be further specified. According to their website (http://www.thedailybeast.com/company/ about-us.html, accessed January 2013), "[t]he combined operation now regularly attracts over 18 million unique online visitors a month and the magazine reaches millions more through its tablet and international editions". Still concerning the process of consumption, "in 2011 The Daily Beast became the online home of Newsweek magazine, which has served as the world's preeminent conversation starter since its founding in 1933". (http://www.thedailybeast.com/ company/about-us.html). Thus, this international magazine and its large international audience seem to resonate well with line 10) "On the journey ahead" in the advertisement. Perhaps this line is, after all, also a direct way of addressing an audience used to travelling.

From this brief discussion of some aspects of the processes of production and consumption, it is possible to interpret, in very general lines, that the discourse practice in which the Diners Club International advertisement is embedded involves at least two main identities: 1) a complex multifaceted producer, and 2) a vast international and influential audience.

A last point to be addressed here, as previously indicated, is the presence of possible traces of intertextuality in the advertisement. Going back to the textimage description previously undertaken (Section 3.2), and looking at it from the perspective of intertextuality, there seems to be at least one important trace directly related to the visual organization of the verbal text and the contexts of production/ consumption just examined.

Throughout the 14 lines of the verbal text in the advertisement, it is possible to observe both the use of incomplete clauses and of rhyme between lines 3 and 5 with the words "Forbidding" and "Inviting" and 
between lines 11 and 13 with the words "sea" and "key". However, it is the visual organization of the verbal text, with left alignment and constant line break ups, which suggests more strongly a trace of intertextuality: the verbal text seems to look (and sound) like poetry. The use of poetry for promoting a product or idea, however, is not new in advertising (Wernick, 1991; Cook, 1992). According to Stern (1992, in Proctor et al 2002, p. 32), "advertisements frequently use poetic license to say one thing and mean another, borrowing literary tactics to convey messages by means other than or in addition to the words". Stern (1992, in Proctor et al, 2002, p. 32) also adds that "both literature and advertising share similar creative techniques to say things in ways other than by direct statements of fact".

In the Diners Club International advertisement, the choice for such artistic tactics appears to be further reinforced by the type of door portrayed. Although it is a generic door in terms of "places in the world" , it is not so generic in terms of "social places in the world". That is, heavy wooden doors with metal doorknobs are more typical of privileged contexts in which art (and, consequently, poetry) is a shared value. Massive wooden doors are usually associated with theatres, opera houses, libraries, museums as well as long-established banks and office buildings, mansions, castles and so on. To sum up, the discourse practice in which the advertisement seems to be embedded is one where Diners Club International Ltd makes use of a complex multifaceted production process to address its potential consumers or, "The best of today's New Economy consumers" via an indirect but familiar and high-valued vehicle: art. 


\subsection{Travelling abroad? Don't forget your Diners Club Inter- national credit card: explaining the sociocultural practice}

The Diners Club International advertisement presents the action of engaging with a closed door as a re-semiotization of a possible problem to those who travel abroad (and read Newsweek!) and the credit card advertised as the solution. The problem, however, is not directly addressed in the advertisement. The use of a highly interpersonal and iconic photo of a generic door, the poetic construction of the textual structure, and the complex production/ consumption context of the advertisement, previously discussed, seem to suggest the problem, construing a hazy set of meanings regarding who is saying what to whom. According to Fairclough's (2003) concept of the logic of appearances, the problem is thus taken "at face value rather than considering it as the causal effect of structures". There is no concrete argumentation or real examples; the logic of appearances successfully turns the daunting interaction with "over land/over sea" doors into an unquestionable and inevitable fact in the context of travelling abroad. The question left open, however, is why? What is the ideological message behind this problem?

Besides the more obvious capitalist reason that such logic of appearances would influence and direct consumer behaviour towards acquiring the Diners Club International credit card, we also see the possibility of two other deeply entangled reasons. The first one has to do with the issue of human togetherness (Bauman 2007). We usually open doors to people we know and trust. However, before we know and trust these people, we need to enhance human contact, to expose ourselves and to spend time together. All these conditions, however, are not in line with the fluidity of our modern society, which Bauman cleverly qualifies as liquid ${ }^{7}$. In liquid times, there 
is no space for the haunting "responsibility for the Other" which is "inseparable from human togetherness" (Bauman 2007, p. 51). Thus, since we constantly avoid the burden of bonds, the opening of doors becomes a problem. In the context of travelling abroad, the situation becomes even more complex: there is no time to get to know people. The Diners Club International advertisement also offers, therefore, a solution: when facing a closed door, there is neither the need to identify ourselves, nor the risk of not being recognised/trusted, since all one has to do is use his/her credit card.

A second possible reason is related to the increasing colonization of social spaces by consumer markets. For example, in Bauman's work (2007), the author discusses the contemporary attempt at fitting the action of seeking a partner into the shopping-and-buying scheme. In his words (2007, p. 11), "the space stretching between human individuals; that space in which the strings that tie humans together are plaited, and the fences that separate them are built" is now in a process of annexation by consumer markets. In the Diners Club International advertisement, the space between travellers and the world around them seems to follow the very same process. Travelling appears to be reduced to the opening of doors or, in other words, to the consumption of commodities which may be behind these doors, from a hotel room, a dinner table and/or an exhibition, for instance, to a possible commercial deal, in the specific context of a business journey. The long-dated human activity of travelling is being redefined as an object of consumption, and the spontaneous attitude of offering a warm welcome to travellers, which was said to be part of some cultures, looks more and more unfamiliar, peculiar and distant.

The problem presented in the Dinners Club International advertisement, therefore, can be interpreted, at first sight, as a subtle way of creating a need (to open closed doors when travelling abroad) 
to a given product (the Dinners Club International credit card). But, as soon as we look at this problem from the perspective of Bauman's sociological insights, there is the feeling that "promoting the product" is just the tip of the iceberg. What is being left unsaid in the advertisement, the missing explanatory logic, that is, an explanation for the problem in terms of causal relations (Fairclough 2003), seems to add an extra ideological layer to it. Why are doors closed after all? How were they opened before credit cards? Why have credit cards become so important when travelling abroad? How did people travel before? On the one hand, the advertisement seems to be quite transparent to the audience with a simple message "Get your Diners Club International credit card to open doors when you travel abroad". On the other hand, however, it seems to obliterate the idea that "The credit card also helps you with the problem of avoiding human togetherness" and that "Travelling is all about consuming related commodities".

This multi-layered ideological message resonates with Billig's short tale Mickey's Ears (1994, p. 166-169). In this story, the characters Vanessa and John, a couple returning from their vacation in Disneyland, display some degree of superiority, laughing at the Disney culture and mocking serious social theorists. They seem to be aware of what, ideologically, Disney stands for, to the extent that they perform acts of hyper conformity and/or resistance. However, in the end of the story, Billig shows that these characters are, in fact, taking reality for granted. They are completely unaware of those "condemned to oblivion", the producers behind the Disney products they bought. In other words, Billig shows that what is indeed straightforward is the characters' comprehension of reality and not reality itself. The case with the Diners Club International advertisement is similar. Perhaps the intended viewers know that the type of service offered by the 
Diners Club International credit card, despite all its positive aspects, may contribute to a society where credit is a synonym for human trust, and also that travelling can be different from just consuming commodities related to this activity. The intended viewers may also be aware that there are other alternative ways of travelling. A question that remains is: Do they actually see the implications of the advertisement or do they believe they see them?

\section{Conclusion}

The multimodal analysis of the Diners Club International advertisement has revealed how textimage constructs a complex problem-solution structure, which along with the visual organization of the verbal text, the presence of rhyme in it, and even the social contexts associated with the type of door portrayed, echo the qualities of art and poetry. Thus, by means of a complex and multifaceted semiotic production process the advertisement addresses a vast international and influential target audience. Together, the set of strategies seems to legitimize the problem of opening doors "over land/over sea" without direct statements of fact, using the logic of appearances. However, when looking at the problem from Bauman's (2007) perspective, for instance, suddenly a multi-layered ideological message also seems to emerge from it. That is, the problem-solution structure in the advertisement not only creates a need (problem) for a product (solution) but taps on two important contemporary social issues: the liquid avoidance of human togetherness and the colonization of travelling by consumer markets. Such a multilayered ideology, therefore, puts in question the extent to which the well-educated target audience is aware of the messages in the advertisement or just believes that they are. 


\section{Notes}

1. This paper was funded by the Brazilian Research Council CNPq, Proc. n. 311551/2011-4.

2. Textimage is a term we borrow from Mitchell $(1995$, p. 89). It designates "composite, synthetic works (or concepts) that combine image and text" (Section 2 ahead).

3. By the adjective small, we mean that it does not correspond to the real/ natural size of credit cards.

4. The use of bold letters and left alignment follows the original text in the advertisement. We have numbered the lines of the text in order to facilitate references in the analysis (Sections 3.2 and 3.3).

5. We would like to thank Záira Bomfante Santos for mentioning this in her brief analysis of the same advertisement during the $17^{\circ}$ INPLA (Intercâmbio em Pesquisa de Linguística Aplicada) at PUC SP.

6. By "places in the world", we are referring to lines 10 and 11 which place the closed door in the context of journeys over land and/or over sea.

7. 'Liquid modernity' is a concept that Bauman develops in many different books, such as Liquid Modernity (2000), Liquid Life (2005), Liquid Fear (2006), Liquid Times (2007), Liquid Love (2003). In a broad sense, Bauman explains that in contrast to solids, which are fixed, closely bounded, and can be linked to human togetherness, fluids/liquids are mobile, varied and shifty, which resonates with the context of the present investigation.

\section{References}

Bauman, Z. (2007). Consuming life. Cambridge \& Malden: Polity Press.

Billig, M. (1994). Sod Baudrillard! Or ideology critique in Disney's world. In: Herbert W. Simons \& Michael Billig. (Eds.), Chapter 7. After postmodernism: reconstructing ideology critique, London: Sage.

Caldas-Coulthard, C. R. (1997). News as social practice. Florianópolis:ARES.

Cook, G. (1992). The discourse of advertising. London: Routledge. 
Cope, B., \& Kalantzis, M. (2000). Multiliteracies: literacy learning and the design of social futures. London: Routledge.

Fairclough, N. (1995). Media discourse. London: Edward Arnold. . (2003). Analysing discourse: textual analysis for social research. London \& New York: Routledge. . (2010). Critical discourse analysis. (2nd. Ed). London: Longman.

Halliday, M. A. K., \& Matthiessen, C. M. I. M. (2004). An introduction to functional grammar. London: Hodder Arnold.

Hoey, M., \& Winter, E. (1986). Clause relations and the writer's communicative task. In: B. Couture. (Ed.), Functional approaches to writing: research perspectives. (pp.120-141). Norwood, NJ: Ablex.

Hoey, M. (2001). Textual interactions: an introduction to written discourse analysis. London: Routledge.

Jordan, M. (1984). Rhetoric of everyday English texts. London: George Allen \& Unwin.

Kalantzis, M., \& Cope, B. (2012). Literacies. Cambridge: Cambridge University Press.

Kress, G., \& van Leeuwen, T.(1996). Reading images: the grammar of visual design. London: Routledge.

. (2001). Multimodal discourse: the modes and media of contemporary communication. London: Arnold.

(2006). Reading images: the grammar of visual design. 2. Ed. London: Routledge.

McCarthy, M., \& Hewings, M. (1988). An alternative approach to the analysis of text. In: Sonderdruck aus PRAXIS des neusprachlichen Unterrichts heft. Dortmund: Verlag Lambert Lensing.

Meurer, J. L. (1997). Relações oracionais e estrutura básica de texto: situação-avaliação. In: J. L. Meurer \& D. Motta-Roth. (Eds.), Parâmetros de textualização. (pp.13-28). Santa Maria, RS: Editora da UFSM.

Mitchell, W. J. T. (1995). Picture theory. Chicago \& London: The University of Chicago Press. 
134 Sidnéa Nunes Ferreira and Viviane M. Heberle, Text Linguistics...

Proctor, S., Proctor, T., \& Papasolomou-Doukakis, I. (2002). A post-modern perspective on advertisements and their analysis. Journal of Marketing Communications, 8:31- 44.

Stern, B. B. (1992) Crafting advertisers: literary versus literal deceptiveness. Journal of Public Policy \& Marketing 11 (1), 72-81.

Unsworth, L. (2001). Teaching multiliteracies across the curriculum - Changing contexts of text and image in classroom practice. Buckingham/Philadelphia: Open University Press.

Wernick, A. (1991). Promotional Culture. London: Sage.

[Received in 05/04/2013. Approved in 05/07/2013] 